\title{
Australian Journal of \\ Changes in physicochemical properties of Gac fruit (Momordica cochinchinensis Spreng.) during storage
}

\author{
Xuan T. Tran ${ }^{1}$, Sophie E. Parks ${ }^{1,2 *}$, Minh H. Nguyen ${ }^{1,3}$, Paul D. Roach ${ }^{1}$, Tuyen C. Kha ${ }^{4}$ \\ ${ }^{1}$ School of Environmental and Life Sciences, University of Newcastle, Ourimbah NSW 2258, Australia \\ ${ }^{2}$ Central Coast Primary Industries Centre, NSW Department of Primary Industries, Ourimbah, NSW 2258, \\ Australia \\ ${ }^{3}$ School of Science and Health, Western Sydney University, Penrith, NSW 2751, Australia \\ ${ }^{4}$ Faculty of Food Science and Technology, Nong Lam University, Ho Chi Minh City, Viet Nam
}

\section{*Corresponding author: sophie.parks@dpi.nsw.gov.au}

\begin{abstract}
Gac fruits were evaluated during storage to observe detailed changes in aril quality (lycopene, $\beta$-carotene and oil concentration). The relationships of these qualities with fruit firmness, skin colour and the total soluble solids (TSS) of aril were also explored to identify any potential indicators of aril quality. Mature fruit were manually picked and sorted for size from two field crops in Vietnam and a greenhouse crop in Australia. They were stored in plastic containers at ambient conditions until the fruit was considered unsalable ( 7 days at $30^{\circ} \mathrm{C}$ in Vietnam and 21 days at $21^{\circ} \mathrm{C}$ in Australia). Storage for a week generally improved aril quality in terms of increasing the concentrations of lycopene (up to $4.3 \mathrm{mg} \mathrm{g}^{-1}$ dry weight), $\beta$-carotene (up to $1.5 \mathrm{mg} \mathrm{g}^{-1}$ dry weight) and oil (up to $0.4 \mathrm{~g} \mathrm{~g}^{-1}$ dry weight) and these were strongly correlated with firmness (lycopene $-0.923, \beta$-carotene -0.754 , oil $-0.764, \mathrm{p}<0.01$ ) and TSS (lycopene $-0.747, \beta$-carotene -0.664 , oil $-0.672, \mathrm{p}<0.01)$. However, quality declined with further storage. Skin colour did not relate well to aril quality but fruit firmness and aril TSS are candidates in the development of simple indices for the quality management of commercial Gac fruit.
\end{abstract}

Received 27 Sep 2016; Revised 22 Dec 2016; Accepted 17 Feb 2017.

Keywords: tropical fruit, Cucurbitaceae, ripening.

\section{Introduction}

Gac (Momordica cochinchinensis Spreng.) is a tropical vine fruit that belongs to the Cucurbitaceae family. Interest is increasing in this fruit as a source of bioactive compounds since the aril surrounding the seed is particularly rich in carotenoids and essential fatty acids (Kha et al., 2013a, Chuyen et al., 2015)

Traditionally, in Vietnam, Gac fruit are harvested by farmers according to the tactile feel of fruit firmness, and by how much of the skin has turned orange. The fruit are stored for between one and four weeks but the effect of storage on the quality of Gac fruit has not been well characterised. In one study limited to the measurement of aril carotenoid contents at one and two weeks of storage, carotenoid contents had significantly declined at two weeks (Nhung et al., 2010). The development of methods to estimate aril quality using readily-available instruments such as a penetrometer for fruit firmness or a colorimeter to detect skin colour changes would improve the management of fruit quality at harvest and during postharvest.

The effect of storage on aril qualities such as oil content has not been investigated but has health and commercial implications. For example, understanding how the oil content or volume extracted from aril is affected by storage is useful commercially since the oil is currently extracted and sold as a health supplement. Further, the oil has the potential to be used as a healthy alternative to saturated fatty acids in the diet (Kha et al., 2013a) and the extraction and use of Gac oil in poor households has been identified as an important measure to improve family health and nutrition in Vietnam (Vuong and King, 2003).

The nutritional quality of Gac fruit is potentially affected by intrinsic factors such as variety and stage of maturity, and by extrinsic influences like growing and storage conditions. The stage of fruit maturity has a strong effect on aril quality. For example, Gac fruit harvested at a fully ripened stage were of a higher quality than less ripe fruits in terms of their carotenoid concentrations (Nhung et al., 2010, Kubola and Siriamornpun, 2011) and oil concentrations (Tran et al., 2015). This species also has high genetic diversity and is associated with morphologically diverse fruits (Wimalasiri et al., 2016). This may also translate to variations in fruit quality as has been shown for varieties of the closely related bitter melon (Momordica charantia) (Tan et al., 2014). Such potential intrinsic and extrinsic factors need consideration prior to conducting postharvest studies. In the current study, sourcing material from contrasting growing and storage conditions has provided data with a broader scope of inference compared with previous Gac studies which generally used material with a common history (Golding and Spohr, 2015).

Since the time between harvest and consumption of Gac can be weeks and large changes in aril carotenoid concentrations can occur during storage, more detail of these 
Table 1. Production and postharvest conditions for the three experiments.

\begin{tabular}{lcccc}
\hline $\begin{array}{l}\text { Harvest } \\
\text { month }\end{array}$ & Location & Growing system & $\begin{array}{c}\text { Postharvest storage } \\
\text { temperature }\end{array}$ & Days stored \\
\hline December 2011 & Vietnam & Soil / Outdoors & $30{ }^{\circ} \mathrm{C}$ & 7 \\
$\begin{array}{l}\text { December 2012 } \\
\text { March 2013 }\end{array}$ & Vietnam & Soil / Outdoors & $30{ }^{\circ} \mathrm{C}$ & 7 \\
\hline
\end{tabular}

changes is required alongside the measurement of other aril qualities and postharvest traits that may also be affected. Thus, the purpose of this study was to evaluate the impact of postharvest storage on some physiochemical characteristics of mature Gac fruit including weight loss, skin colour and firmness of the entire fruit, and for the aril surrounding the seeds: TSS, and the concentrations of oil, lycopene and $\beta$ carotene. The relationships between the aril qualities of nutritional value (carotenoid and oil concentrations) and several traits commonly measured during postharvest (skin colour, TSS and firmness) were also explored to identify any potential indicators of aril quality for future work.

\section{Results}

The Gac fruit in this study from both Vietnam and Australia were similar in their whole fruit and aril weights. The proportion of aril in the fruit did not relate to fruit weight in any of the experiments (data not shown).

\section{Whole-fruit quality changes during storage}

During storage, weight loss increased and this was associated with a significant decline in firmness for all three experiments (Tables 2, 3 and 4). At the beginning of storage, the Vietnamese fruit were generally firmer than the Australian fruit but all fruit were similar in firmness at one week of storage.

Skin colour as indicated by the degree of lightness or darkness (L), vividness (chroma), and the tint of the colour (hue angle) did not reveal any general trends during storage of gac fruit (Tables 2, 3 and 4). However, the Australian fruit were generally more vivid in colour, indicated by a higher range of chroma values. Also, the Vietnamese fruit from 2012 declined in hue and chroma values, signifying that the skin became redder, and duller with storage time (Table 3 ).

\section{Aril quality changes during storage}

The TSS of the aril appeared slightly higher for the Australian fruit compared with the Vietnamese fruit at the beginning of storage but all aril significantly increased in TSS with storage time to similar levels. In general, the contents of oil, $\beta$-carotene and lycopene in the aril of Gac fruit either increased or remained stable with at least 7 days storage. In the Australian fruit, which was stored for longer and at a lower temperature than the Vietnamese fruit, the decline in these qualities was marked after 12 days of storage (Table 4). Although the two Vietnamese fruit samples from 2011 and 2012 were very similar in most qualities, they were dissimilar in their range of values for $\beta$-carotene and lycopene contents (Table 7).

\section{Interactions of whole fruit and aril characteristics}

With storage up to 7 days $(2011,2012)$, TSS, lycopene, $\beta$ carotene and oil increased in aril, and fruit firmness decreased. These variables were related (Tables $5 \& 6$ ). However, storage for longer than 12 days (2013) was associated with a reduction in lycopene, $\beta$-carotene and oil and these values did not relate well to the associated increases in TSS or to the reduction in firmness (Table 7).

The TSS of aril was positively correlated with lycopene, $\beta$ carotene and oil concentration in 2011 and 2012 (Tables 5 \& $6)$. In 2013, TSS was negatively correlated with lycopene, $\beta$ carotene and oil content (Table 7).

Fruit firmness was negatively correlated to lycopene, $\beta$ carotene and oil concentration in aril in 2011 and 2012 (Tables 5 and 6). In 2013, firmness was positively correlated with lycopene and $\beta$-carotene but negatively correlated with oil concentration (Table 7).

Fruit firmness was negatively correlated to aril TSS in 2011 $(\mathrm{r}=-0.764), 2012(\mathrm{r}=-0.805)$ and $2013(\mathrm{r}=-0.675)$.

The colourmetric measurements of the skin, chroma and hue angle, were negatively correlated with lycopene and $\beta$ carotene in aril, but only in 2012 (Table 6).

\section{Discussion}

This study raises the possibility of postharvest ripening and prolonged storage of semi-ripened fruit, without having to compromise on nutritional value. However, the development of objective quality measures will be required to assist in managing fruit quality during postharvest and some are proposed here.

The traits with high nutritional value, being the oil, lycopene and $\beta$-carotene contents in aril, increased during storage. These remained stable at maximum levels during storage for up to about 12 days at $21^{\circ} \mathrm{C}$ (Table 3). Their maximum levels were comparable to fully vine-ripened fruits grown from the same Australian plants in a previous study (Tran et al., 2015). These findings corroborate the previous observation that under-ripe Gac fruit have increased lycopene contents in aril at one week of storage, similar to levels obtained in stored medium and fully ripened fruits (Nhung et al., 2010). Ripening in Gac requires further investigation in order to estimate stage of ripeness and for managing ripening under controlled conditions. For instance, the effect of temperature needs consideration since in bitter melon (Momordica charantia), postharvest ripening of fruits at $35^{\circ} \mathrm{C}$ generally inhibited lycopene synthesis in the aril in contrast to its steady accumulation at $25^{\circ} \mathrm{C}$ (Tran and Raymundo, 1999).

During the storage of Gac fruit, significant weight loss, softening and increases in TSS occurred, characteristic of ripening in a number of fruits such as mango (Baloch and Bibi, 2012) and pomegranate (Olaniyi and Umezuruike, 2013). Fruit firmness and TSS have some promise as postharvest quality indicators in Gac. TSS may be particularly useful since it can easily be measured in the aril juice using a hand-held refractometer. Fruit firmness and TSS were well correlated with the carotenoids and oil contents in both the Vietnamese fruit sets. These were not well related in the Australian fruit, probably because the oil content declined after about 9 days of storage. Although colourmetric measures of skin can distinguish between different stages of Gac fruit maturity (Tran et al., 2015), in this study, the skin colour changes that occurred during storage occurred in and were related to carotenoid contents in only one of the three experiments. The uneven development of the orange colour 
Table 2. Some properties of stored mature fruits (weight loss, firmness, skin colour) and their aril concentrations of oil, $\beta$-carotene and lycopene for Gac grown in Vietnam in $2011\left(30 \pm 1^{\circ} \mathrm{C}\right)$.

\begin{tabular}{|c|c|c|c|c|c|c|c|c|c|}
\hline \multirow{2}{*}{$\begin{array}{l}\text { Storage time } \\
\text { (day) }\end{array}$} & \multirow[t]{2}{*}{ Weight loss (\%) } & \multirow[t]{2}{*}{ Firmness (kgf) } & \multirow{2}{*}{$\begin{array}{l}\text { TSS } \\
\left({ }^{\circ} \text { Brix }\right)\end{array}$} & \multicolumn{3}{|c|}{ Fruit skin colour } & \multirow{2}{*}{$\begin{array}{l}\text { Oil } \\
\left(\mathrm{g} \mathrm{g}^{-1} \mathrm{DW}\right)\end{array}$} & \multirow{2}{*}{$\begin{array}{l}\beta \text {-carotene } \\
\left(\mathrm{mg} \mathrm{g}^{-1} \mathrm{DW}\right)\end{array}$} & \multirow{2}{*}{$\begin{array}{l}\text { Lycopene } \\
\left(\mathrm{mg} \mathrm{g}^{-1} \mathrm{DW}\right.\end{array}$} \\
\hline & & & & $\mathrm{L}$ & $\mathrm{C}$ & $\mathrm{H}^{\mathrm{o}}$ & & & \\
\hline 0 & $0.00 \pm 0.00^{\mathrm{a}}$ & $6.86 \pm 0.25^{f}$ & $9.78 \pm 0.08^{\mathrm{a}}$ & $41.60 \pm 0.90^{b}$ & $55.74 \pm 0.63^{\mathrm{c}}$ & $54.67 \pm 0.85^{\mathrm{a}}$ & $0.16 \pm 0.01^{\mathrm{a}}$ & $0.49 \pm 0.06^{\mathrm{a}}$ & $0.68 \pm 0.03^{\mathrm{a}}$ \\
\hline 1 & $0.23 \pm 0.09^{\mathrm{a}}$ & $6.17 \pm 0.15^{\mathrm{e}}$ & $10.64 \pm 0.29^{\mathrm{ac}}$ & $43.05 \pm 0.90^{\mathrm{bc}}$ & $55.20 \pm 0.31^{\mathrm{bc}}$ & $53.00 \pm 1.49^{\mathrm{a}}$ & $0.19 \pm 0.01^{\mathrm{ab}}$ & $0.82 \pm 0.21^{\mathrm{a}}$ & $1.40 \pm 0.14^{\mathrm{b}}$ \\
\hline 2 & $0.30 \pm 0.06^{\mathrm{a}}$ & $5.68 \pm 0.23^{\mathrm{e}}$ & $11.53 \pm 0.18^{\mathrm{ab}}$ & $41.95 \pm 0.70^{\mathrm{bc}}$ & $49.92 \pm 1.04^{\mathrm{ab}}$ & $48.67 \pm 0.90^{\mathrm{a}}$ & $0.22 \pm 0.01^{\mathrm{b}}$ & $1.19 \pm 0.09^{\mathrm{b}}$ & $1.76 \pm 0.17^{\mathrm{b}}$ \\
\hline 3 & $0.73 \pm 0.19^{\mathrm{b}}$ & $4.91 \pm 0.26^{\mathrm{d}}$ & $14.07 \pm 1.07^{\mathrm{bc}}$ & $39.65 \pm 1.31^{\mathrm{ab}}$ & $49.09 \pm 1.95^{\mathrm{a}}$ & $48.87 \pm 2.90^{\mathrm{a}}$ & $0.33 \pm 0.01^{\mathrm{c}}$ & $0.80 \pm 0.07^{\mathrm{a}}$ & $1.75 \pm 0.11^{\mathrm{b}}$ \\
\hline 4 & $1.40 \pm 0.12^{\mathrm{b}}$ & $4.19 \pm 0.15^{\mathrm{c}}$ & $13.25 \pm 0.94^{\mathrm{abc}}$ & $36.87 \pm 2.30^{\mathrm{a}}$ & $46.57 \pm 2.19^{\mathrm{a}}$ & $43.05 \pm 3.69^{\mathrm{a}}$ & $0.40 \pm 0.03^{\mathrm{d}}$ & $1.19 \pm 0.06^{\mathrm{b}}$ & $2.23 \pm 0.10^{c}$ \\
\hline 5 & $3.43 \pm 0.64^{\mathrm{c}}$ & $3.41 \pm 0.09^{\mathrm{b}}$ & $15.53 \pm 1.44^{\text {cde }}$ & $41.26 \pm 0.33^{\mathrm{b}}$ & $50.78 \pm 1.92^{\mathrm{ac}}$ & $47.42 \pm 1.79^{\mathrm{a}}$ & $0.40 \pm 0.03^{\mathrm{d}}$ & $1.17 \pm 0.06^{\mathrm{b}}$ & $2.46 \pm 0.27^{\mathrm{c}}$ \\
\hline 6 & $4.10 \pm 0.40^{\mathrm{cd}}$ & $2.89 \pm 0.15^{\mathrm{b}}$ & $15.60 \pm 2.64^{\text {cde }}$ & $42.79 \pm 2.11^{\mathrm{bc}}$ & $50.03 \pm 3.17^{\mathrm{ab}}$ & $48.11 \pm 3.42^{\mathrm{a}}$ & $0.33 \pm 0.01^{\mathrm{c}}$ & $1.34 \pm 0.15^{\mathrm{b}}$ & $2.80 \pm 0.20^{\mathrm{c}}$ \\
\hline 7 & $4.43 \pm 0.47^{\mathrm{d}}$ & $2.03 \pm 0.26^{\mathrm{a}}$ & $18.13 \pm 0.93^{\text {ef }}$ & $45.90 \pm 1.01^{\mathrm{c}}$ & $54.66 \pm 1.06^{\mathrm{bc}}$ & $50.39 \pm 2.08^{\mathrm{a}}$ & $0.34 \pm 0.02^{\mathrm{c}}$ & $1.49 \pm 0.13^{\mathrm{b}}$ & $3.50 \pm 0.20^{\mathrm{d}}$ \\
\hline
\end{tabular}

The values are means $\pm \mathrm{SE}(\mathrm{n}=3)$ and those sharing the same superscript in a column are not significantly different $(\mathrm{p}<0.05)$ as determined by ANOVA and the LSD post-hoc test.

Table 3. Some properties of stored mature fruits (weight loss, firmness, skin colour) and their aril concentrations of oil, $\beta$-carotene and lycopene for Gac grown in Vietnam in $2012\left(30 \pm 1^{\circ} \mathrm{C}\right)$.

\begin{tabular}{|c|c|c|c|c|c|c|c|c|c|c|}
\hline \multirow{2}{*}{$\begin{array}{l}\text { Storage } \\
\text { time (day) }\end{array}$} & \multirow{2}{*}{$\begin{array}{l}\text { Weight } \\
(\%)\end{array}$} & \multirow[t]{2}{*}{ loss } & \multirow[t]{2}{*}{ Firmness (kgf) } & \multirow{2}{*}{$\begin{array}{l}\text { TSS } \\
\left({ }^{\circ} \text { Brix }\right)\end{array}$} & \multicolumn{3}{|c|}{ Fruit skin colour } & \multirow{2}{*}{$\begin{array}{l}\text { Oil } \\
\left(\mathrm{g} \mathrm{g}^{-1} \mathrm{DW}\right)\end{array}$} & \multirow{2}{*}{$\begin{array}{l}\beta \text {-carotene } \\
\left(\mathrm{mg} \mathrm{g}^{-1} \mathrm{DW}\right)\end{array}$} & \multirow{2}{*}{$\begin{array}{l}\text { Lycopene } \\
\left(\mathrm{mg} \mathrm{g}^{-1} \mathrm{DW}\right)\end{array}$} \\
\hline & & & & & $\mathrm{L}$ & $\mathrm{C}$ & $\mathrm{H}^{\mathrm{O}}$ & & & \\
\hline 0 & $0.00 \pm 0.00^{\mathrm{a}}$ & & $7.79 \pm 0.17^{\mathrm{e}}$ & $9.57 \pm 0.28^{\mathrm{a}}$ & $41.76 \pm 0.82^{\mathrm{a}}$ & $55.63 \pm 1.27^{\mathrm{d}}$ & $55.50 \pm 1.09^{\mathrm{b}}$ & $0.16 \pm 0.01^{\mathrm{a}}$ & $0.37 \pm 0.07^{\mathrm{a}}$ & $0.18 \pm 0.04^{\mathrm{a}}$ \\
\hline 1 & $0.70 \pm 0.21^{\mathrm{a}}$ & & $6.75 \pm 0.51^{\mathrm{d}}$ & $10.07 \pm 0.11^{\mathrm{a}}$ & $41.45 \pm 2.43^{\mathrm{a}}$ & $53.96 \pm 0.97^{\mathrm{cd}}$ & $50.59 \pm 0.38^{c}$ & $0.21 \pm 0.02^{\mathrm{b}}$ & $0.48 \pm 0.07^{\mathrm{ab}}$ & $0.99 \pm 0.34^{\mathrm{b}}$ \\
\hline 2 & $0.63 \pm 0.09^{\mathrm{a}}$ & & $5.46 \pm 0.21^{\mathrm{c}}$ & $11.34 \pm 0.22^{\mathrm{abc}}$ & $40.55 \pm 1.42^{\mathrm{a}}$ & $53.65 \pm 1.96^{\mathrm{cd}}$ & $46.79 \pm 0.85^{\mathrm{ac}}$ & $0.25 \pm 0.01^{\mathrm{b}}$ & $0.62 \pm 0.08^{\mathrm{bc}}$ & $1.86 \pm 0.34^{\mathrm{c}}$ \\
\hline 3 & $1.40 \pm 0.29^{\mathrm{b}}$ & & $4.77 \pm 0.08^{c}$ & $13.99 \pm 1.00^{\mathrm{bc}}$ & $36.08 \pm 2.41^{\mathrm{a}}$ & $51.41 \pm 1.91^{\mathrm{cd}}$ & $48.08 \pm 0.82^{\mathrm{c}}$ & $0.41 \pm 0.02^{\mathrm{c}}$ & $0.75 \pm 0.12^{\mathrm{c}}$ & $1.64 \pm 0.08^{c}$ \\
\hline 4 & $1.80 \pm 0.15^{\mathrm{b}}$ & & $3.70 \pm 0.54^{\mathrm{b}}$ & $13.20 \pm 0.90^{\mathrm{cd}}$ & $37.72 \pm 1.73^{\mathrm{a}}$ & $48.09 \pm 1.70^{\mathrm{ac}}$ & $44.51 \pm 2.93^{\mathrm{a}}$ & $0.40 \pm 0.02^{\mathrm{c}}$ & $1.04 \pm 0.06^{\mathrm{d}}$ & $2.27 \pm 0.25^{\mathrm{c}}$ \\
\hline 5 & $3.23 \pm 0.28^{\mathrm{c}}$ & & $3.55 \pm 0.18^{\mathrm{b}}$ & $15.72 \pm 1.28^{\mathrm{cde}}$ & $39.20 \pm 0.53^{\mathrm{a}}$ & $51.39 \pm 1.51^{\mathrm{cd}}$ & $45.00 \pm 1.04^{\mathrm{a}}$ & $0.37 \pm 0.02^{\mathrm{c}}$ & $1.07 \pm 0.05^{\mathrm{d}}$ & $3.26 \pm 0.06^{\mathrm{d}}$ \\
\hline 6 & $4.00 \pm 0.26^{\mathrm{d}}$ & & $2.59 \pm 0.10^{\mathrm{a}}$ & $17.63 \pm 2.05^{\mathrm{e}}$ & $41.38 \pm 2.42^{\mathrm{a}}$ & $49.73 \pm 2.15^{\mathrm{abc}}$ & $43.42 \pm 2.32^{\mathrm{a}}$ & $0.36 \pm 0.01^{\mathrm{c}}$ & $1.14 \pm 0.05^{\mathrm{d}}$ & $3.76 \pm 0.19^{\mathrm{d}}$ \\
\hline 7 & $4.70 \pm 0.44^{\mathrm{d}}$ & & $1.93 \pm 0.18^{\mathrm{a}}$ & $17.86 \pm 0.92^{\mathrm{e}}$ & $45.19 \pm 2.43^{\mathrm{a}}$ & $46.08 \pm 2.05^{\mathrm{a}}$ & $44.38 \pm 0.63^{\mathrm{a}}$ & $0.36 \pm 0.01^{\mathrm{c}}$ & $1.26 \pm 0.02^{\mathrm{e}}$ & $4.33 \pm 0.09^{\mathrm{e}}$ \\
\hline
\end{tabular}

Table 4. Some properties of stored mature fruits (weight loss, firmness, skin colour) and their aril concentrations of oil, $\beta$-carotene and lycopene for Gac grown in Australia in 2013 ( $21 \pm 1{ }^{\circ} \mathrm{C}$ ).

\begin{tabular}{|c|c|c|c|c|c|c|c|c|c|}
\hline \multirow[t]{2}{*}{ Storage time (days) } & \multirow{2}{*}{$\begin{array}{l}\text { Weight loss } \\
(\%)\end{array}$} & \multirow{2}{*}{$\begin{array}{l}\text { Firmness } \\
\text { (kgf) }\end{array}$} & \multirow{2}{*}{$\begin{array}{l}\text { TSS } \\
\left({ }^{\circ} \text { Brix }\right)\end{array}$} & \multicolumn{3}{|c|}{ Fruit skin colour } & \multirow{2}{*}{$\begin{array}{l}\text { Oil } \\
\left(\mathrm{g} \mathrm{g}^{-1} \mathrm{DW}\right)\end{array}$} & \multirow{2}{*}{$\begin{array}{l}\beta \text {-carotene } \\
\left(\mathrm{mg} \mathrm{g}^{-1} \mathrm{DW}\right)\end{array}$} & \multirow{2}{*}{$\begin{array}{l}\text { Lycopene } \\
\left(\mathrm{mg} \mathrm{g}^{-1} \mathrm{DW}\right)\end{array}$} \\
\hline & & & & $\mathrm{L}$ & $\mathrm{C}$ & $\mathrm{H}^{\mathrm{o}}$ & & & \\
\hline 0 & $0.00 \pm 0.00^{\mathrm{a}}$ & $2.73 \pm 0.08^{\mathrm{e}}$ & $12.10 \pm 0.98^{\mathrm{a}}$ & $35.76 \pm 2.27^{\mathrm{a}}$ & $56.84 \pm 1.69^{\mathrm{a}}$ & $44.60 \pm 2.38^{\mathrm{ab}}$ & $0.23 \pm 0.01^{\mathrm{b}}$ & $1.35 \pm 0.29^{\mathrm{a}}$ & $1.85 \pm 0.06^{\mathrm{a}}$ \\
\hline 3 & $3.47 \pm 0.33^{b}$ & $2.36 \pm 0.10^{\mathrm{d}}$ & $13.07 \pm 0.53^{\mathrm{a}}$ & $40.95 \pm 1.54^{\mathrm{b}}$ & $57.75 \pm 5.42^{\mathrm{a}}$ & $48.53 \pm 3.22^{\mathrm{ab}}$ & $0.21 \pm 0.01^{\mathrm{b}}$ & $1.10 \pm 0.15^{\mathrm{ab}}$ & $1.96 \pm 0.25^{\mathrm{a}}$ \\
\hline 6 & $3.76 \pm 0.51^{\mathrm{bc}}$ & $2.20 \pm 0.06^{\mathrm{cd}}$ & $13.32 \pm 1.61^{\mathrm{ab}}$ & $37.43 \pm 1.72^{\mathrm{ab}}$ & $60.11 \pm 2.31^{\mathrm{a}}$ & $50.01 \pm 2.06^{\mathrm{bc}}$ & $0.21 \pm 0.00^{b}$ & $1.31 \pm 0.14^{\mathrm{a}}$ & $1.85 \pm 0.21^{\mathrm{a}}$ \\
\hline 9 & $5.45 \pm 0.49^{\mathrm{cd}}$ & $2.05 \pm 0.06^{\mathrm{c}}$ & $13.65 \pm 0.94^{\mathrm{ab}}$ & $38.39 \pm 2.72^{\mathrm{ab}}$ & $52.55 \pm 1.25^{\mathrm{a}}$ & $45.33 \pm 3.33^{\mathrm{ab}}$ & $0.25 \pm 0.01^{\mathrm{a}}$ & $1.16 \pm 0.11^{\mathrm{ab}}$ & $2.32 \pm 0.21^{\mathrm{a}}$ \\
\hline 12 & $6.59 \pm 0.68^{\mathrm{de}}$ & $1.78 \pm 0.14^{\mathrm{bc}}$ & $14.30 \pm 0.98^{\mathrm{bc}}$ & $33.43 \pm 1.56^{\mathrm{a}}$ & $56.26 \pm 0.07^{\mathrm{a}}$ & $43.28 \pm 1.83^{\mathrm{ac}}$ & $0.24 \pm 0.01^{\mathrm{a}}$ & $1.05 \pm 0.09^{\mathrm{ab}}$ & $2.45 \pm 0.20^{\mathrm{a}}$ \\
\hline 15 & $8.25 \pm 0.68^{\mathrm{e}}$ & $1.78 \pm 0.08^{\mathrm{ab}}$ & $14.64 \pm 0.53^{\mathrm{bc}}$ & $38.05 \pm 0.60^{\mathrm{ab}}$ & $56.88 \pm 2.86^{\mathrm{a}}$ & $42.29 \pm 3.79^{\mathrm{ac}}$ & $0.21 \pm 0.01^{\mathrm{b}}$ & $1.12 \pm 0.17^{\mathrm{ab}}$ & $1.28 \pm 0.25^{\mathrm{a}}$ \\
\hline 18 & $14.00 \pm 1.09^{\mathrm{f}}$ & $1.60 \pm 0.04^{\mathrm{a}}$ & $15.81 \pm 0.59^{\mathrm{cd}}$ & $41.49 \pm 1.43^{\mathrm{b}}$ & $56.26 \pm 2.28^{\mathrm{a}}$ & $52.01 \pm 2.36^{\mathrm{b}}$ & $0.19 \pm 0.01^{\mathrm{c}}$ & $0.65 \pm 0.06^{\mathrm{b}}$ & $0.70 \pm 0.06^{\mathrm{b}}$ \\
\hline 21 & $11.56 \pm 2.15^{\mathrm{f}}$ & $1.65 \pm 0.14^{\mathrm{a}}$ & $16.75 \pm 0.28^{\mathrm{d}}$ & $36.60 \pm 1.30^{\mathrm{ab}}$ & $56.17 \pm 1.48^{\mathrm{a}}$ & $41.83 \pm 0.46^{\mathrm{a}}$ & $0.19 \pm 0.01^{\mathrm{c}}$ & $0.66 \pm 0.06^{\mathrm{b}}$ & $0.70 \pm 0.12^{\mathrm{b}}$ \\
\hline
\end{tabular}
The values are means $+\mathrm{SE}(\mathrm{n}=3)$ and those sharing the same superscript in a column are not significantly different $(\mathrm{p}<0.05)$ as determined by ANOVA and LSD post-hoc test. 
Table 5. Pearson correlation coefficients (r) among the quality properties of stored Gac fruits in Vietnam in $2011\left(30 \pm 1^{\circ} \mathrm{C}\right)$.

\begin{tabular}{|c|c|c|c|c|c|c|c|c|}
\hline Parameters & 1 & 2 & 3 & 4 & 5 & 6 & 7 & 8 \\
\hline 1. Firmness & 1 & & & & & & & \\
\hline 2. TSS & $-0.803 * *$ & 1 & & & & & & \\
\hline 3. Lightness & -0.200 & 0.347 & 1 & & & & & \\
\hline 4. Chroma & 0.227 & -0.079 & $0.684 * *$ & 1 & & & & \\
\hline 5. Hue angle & 0.334 & 0.000 & $0.640 * *$ & $0.726 * *$ & 1 & & & \\
\hline 6. Oil content & $-0.764 * *$ & $0.672 * *$ & -0.169 & $-0.424 *$ & $-0.516 * *$ & 1 & & \\
\hline 7. Carotene & $-0.754 * *$ & $0.664 * *$ & 0.350 & -0.182 & -0.244 & $0.519 * *$ & 1 & \\
\hline 8. Lycopene & $-0.923 * *$ & $0.747 * *$ & 0.290 & -0.237 & -0.321 & $0.713 * *$ & $0.786 * *$ & 1 \\
\hline
\end{tabular}

$* \mathrm{p}<0.05$ (2- tailed).

$-0.237$

-0.244
-0.321

$0.713^{*}$

$0.786^{* *}$

$\mathrm{p}<0.01$ (2-tailed).

Table 6. Pearson correlation coefficients (r) among the quality properties of stored Gac fruits in Vietnam in $2012\left(30 \pm 1^{\circ} \mathrm{C}\right)$.

\begin{tabular}{|c|c|c|c|c|c|c|c|c|}
\hline Parameters & 1 & 2 & 3 & 4 & 5 & 6 & 7 & 8 \\
\hline 1. Firmness & 1 & & & & & & & \\
\hline 2. TSS & $-0.834 * *$ & 1 & & & & & & \\
\hline 3. Lightness & -0.022 & 0.116 & 1 & & & & & \\
\hline 4. Chroma & $0.702 * *$ & $-0.529 * *$ & -0.092 & 1 & & & & \\
\hline 5. Hue angle & $0.823 * *$ & $-0.558 * *$ & 0.097 & $0.675^{* *}$ & 1 & & & \\
\hline 6. Oil content & $-0.805 * *$ & $0.649 * *$ & -0.347 & $-0.653 * *$ & $-0.708 * *$ & 1 & & \\
\hline 7. Carotene & $-0.919 * *$ & $0.749 * *$ & 0.125 & $-0.766 * *$ & $-0.822 * *$ & $0.775^{* *}$ & 1 & \\
\hline 8. Lycopene & $-0.935 * *$ & $0.842 * *$ & 0.202 & $-0.608 * *$ & $-0.756 * *$ & $0.630^{* *}$ & $0.889 * *$ & 1 \\
\hline
\end{tabular}

* $\mathrm{p}<0.05$ (2- tailed)

Table 7. Pearson correlation coefficients (r) among the quality properties of stored Gac fruits in Australia in $2013\left(21 \pm 1^{\circ} \mathrm{C}\right)$

\begin{tabular}{|c|c|c|c|c|c|c|c|c|}
\hline Parameters & 1 & 2 & 3 & 4 & 5 & 6 & 7 & 8 \\
\hline 1. Firmness & 1 & & & & & & & \\
\hline 2. TSS & $-0.675^{* *}$ & 1 & & & & & & \\
\hline 3. Lightness & -0.114 & 0.311 & 1 & & & & & \\
\hline 4. Chroma & 0.171 & 0.059 & 0.182 & 1 & & & & \\
\hline 5. Hue angle & 0.122 & 0.068 & $0.610 * *$ & $0.442 *$ & 1 & & & \\
\hline 6. Oil content & $-0.408^{*}$ & $-0.443 *$ & -0.222 & -0.324 & -0.088 & 1 & & \\
\hline 7. Carotene & $0.491 *$ & $-0.460 *$ & -0.232 & 0.223 & -0.078 & 0.320 & 1 & \\
\hline 8. Lycopene & $0.439 *$ & $-0.468 *$ & -0.242 & -0.204 & -0.240 & $0.634 * *$ & $0.542 * *$ & 1 \\
\hline
\end{tabular}

$* \mathrm{p}<0.05$ (2- tailed).
$* * \mathrm{p}<0.01$ (2-tailed). 
on the skin as the Gac fruit ripens may render colourmetric measurements too impractical for application.

Firmer fruit from the Vietnamese experiments compared with those from the Australian experiment were potentially less mature, despite efforts to harvest all fruit at a similar stage of maturity. This was perhaps reflected by their slightly lower TSS, lycopene and $\beta$-carotene contents in the aril, characteristic of Gac fruit harvested before they are fully mature (Tran et al., 2015). However, other reasons for the firmer fruit cannot be discounted. In some species, fruit firmness is affected by variety, such as in kiwifruit (Islam et al., 2012). As Gac is high in genetic variability (Wimalasiri et al., 2016), it is possible that some physiochemical differences between the Vietnamese and Australian fruit may have a genetic basis. Further, differences in crop production may also be important. For example, the Australian crop was grown without the inclusion of silicon $(\mathrm{Si})$ which is typical for hydroponic crops. Silicon application has been shown to increase the firmness of tomatoes (Weerahewa and David, 2015) and the absence of Si in the Australian fruit may have contributed to generally softer fruit at harvest.

This study highlights the potential impact of sample origin and provenance on the quality and health value of Gac fruits. Despite the common features of fruit maturity, location and storage regime, the two Vietnamese fruit samples, picked on different occasions, differed in their range of values for carotenoid contents. In this case, obvious sources of variation may have included climate and plant age. In another example, in this study the proportion of aril in the fruit was not related to fruit weight, in contrast to a previous crop from the same genetic stock and growing system (Parks et al.(2013). Further studies on physiochemical measures of Gac fruit need to consider several distinct sources of fruit, preferably with known provenance, to avoid data with limited inference.

\section{Materials and Methods}

Three experiments on Gac fruit storage were conducted for this study, two in Vietnam and one in Australia with contrasting conditions (Table 1).

\section{Crop production}

In Vietnam, a Gac crop was grown from seed in the field in the rural area of Trang Bang, Tay Ninh Province $\left(11^{\circ} 2^{\prime} \mathrm{N}\right.$, $\left.106^{\circ} 22^{\prime} \mathrm{E}\right)$ and harvested at two and three years old in December 2011 and 2012. The plants were grown according to typical practices for Gac production. The plants were fertilised using an organic fertiliser and composted straw. In Australia, a Gac crop was grown from two-year-old root stock in May, 2013 in a climate-controlled greenhouse at the NSW Department of Primary Industries Research Station in Ourimbah, NSW, $\left(151^{\circ} 22^{\prime} \mathrm{E}, 33^{\circ} 21^{\prime} \mathrm{S}\right)$ and was harvested in March, 2014, 13 weeks after pollination. The crop was grown in bags of soilless coir and irrigated and fed using hydroponic nutrient solution. Practices were as described for greenhouse production of Gac in a previous study (Parks et al., 2013).

\section{Harvest, sorting and storage of fruit}

In Vietnam, the fruit were harvested and transported to the laboratory of the Faculty of Food Science and Technology, Nong Lam University, Ho Chi Minh City for storage and analysis. In Australia, the Gac fruits were harvested and stored and analysed at the postharvest facilities on-site. For all three crops, fruits were harvested at a vine-ripened stage and were considered ready-to-eat at picking. This stage of maturity was between 3 and 4 of the Gac maturity scale with orange patches to fully covered orange skin and red aril (Tran et al., 2015).

The Gac fruits were stored in plastic containers under ambient conditions until they appeared unacceptable to consumers (7 days in Vietnam and 21 days in Australia). In Australia, the temperature and the relative humidity $(\mathrm{RH})$ of the preservation room were maintained at $21 \pm 1^{\circ} \mathrm{C}$ and 60 $70 \%$, respectively. In Vietnam, the average temperature of the preservation room was $30 \pm 1^{\circ} \mathrm{C}$ ( $\mathrm{RH}$ not available). For each experiment, the physicochemical properties were determined on three randomly selected fruit, daily for 7 days in the two Vietnamese experiments, and on every third day for 21 days in the Australian experiment.

\section{Measurements on whole fruit}

The weight lost by fruit during storage was calculated as the percentage difference between the initial weight and the final weight of the individual fruit.

The colour $\left(L^{*}, a^{*}, b^{*}\right)$ of fruit skin was measured using a Minolta Chroma Meter CR-400/410 (Minolta Corp, Osaka, Japan). Calculations were made of two colour parameters, based on the equations for chroma $\left[\mathrm{C}^{*}=\left(\mathrm{a}^{* 2}+\mathrm{b}^{* 2}\right)^{0.5}\right]$ and hue angle $\left[\mathrm{H}^{\circ}=\arctan \left(\mathrm{b}^{*} / \mathrm{a}^{*}\right)\right]$ (McLellan et al. (1995). The equatorial axis of the fruit was selected to take the measurements, 10 per fruit.

The firmness of each Gac fruit was determined using a Penetrometer (Facchini, Alfonsine, Italy) with an $8 \mathrm{~mm}$ flat plunger under constant force to penetrate into the fruit. Means of 10 values per fruit were calculated and expressed as kilograms force (kgf).

\section{Measurements on the aril}

The total soluble solids (TSS\%) of the filtered aril juice were measured using a digital refractometer (Atago Co. Ltd, Japan).

The Soxhlet extraction method was used to obtain the total oil content in aril samples (Kha et al.(2013b). These were expressed as $\mathrm{g} \mathrm{g}^{-1}$ of dry weight. In brief, hexane was used as the solvent and the oil extract was dried at $70^{\circ} \mathrm{C}$ to constant weight.

High performance liquid chromatography (HPLC) was used to obtain the contents of $\beta$-carotene and lycopene in aril (Kha et al.(2013b) and these were expressed as $\mathrm{mg} \mathrm{g}^{-1}$ of fresh weight. Briefly, an ethanol: hexane (4:3, v:v) solvent was used for the extraction. The Agilent 1200 and Shimadzu LC-10AD HPLC systems were used with coupled Luna C18 and Jupiter $\mathrm{C} 18$ columns and the $20 \mu \mathrm{l}$ volumes were injected at a flow rate of $1.0 \mathrm{~mL} \mathrm{~min}^{-1}$ and detected at $450 \mathrm{~nm}$.

\section{Statistical analyses}

Data were assessed by analysis of variance (ANOVA) and the least significant difference (LSD) post-hoc test $(95 \%$ confidence interval) was employed to separate means using the SPSS-PASW GradPack 22.0 for Mac (IBM Corp., Armonk, NY, USA). Correlation coefficients (r) were determined by Pearson's correlation matrix method also using SPSS software.

\section{Conclusion}

We have established that Gac fruit harvested prior to full maturity can increase their nutritional qualities, in terms of oil, lycopene and $\beta$-carotene contents in aril, postharvest. 
With further work, it may be possible to use a simple measurement of TSS in aril juice or whole-fruit firmness to indicate fruit quality during ripening. Investigations are required to determine the appropriate storage conditions for maximising and maintaining fruit quality. Ensuring that sources of fruit used in Gac research are not limited in their inference is important for the application of new postharvest techniques that are developed for use in a commercial context.

\section{Acknowledgements}

The Vietnamese Government and the University of Newcastle, Australia, supported a PhD scholarship for Xuan Thi Tran during this study. Dr Wei Liang and Dr Barbara Blades at Central Coast Primary Industries Centre, NSW Department Primary Industries also provided technical assistance.

\section{References}

Baloch MK, Bibi F (2012) Effect of harvesting and storage conditions on the post harvest quality and shelf life of mango (Mangifera indica L.) fruit. S Afr J Bot. 83:109116.

Chuyen HV, Nguyen MH, Roach PD, Golding JB, Parks SE (2015) Gac fruit (Momordica cochinchinensis Spreng.): a rich source of bioactive compounds and its potential health benefits. Int J Food Sci Tech. 50:567-577.

Golding JB, Spohr LJ (2015) Postharvest technology experimentation: Solutions to common problems. In Advances in Postharvest Fruit and Vegetable Technology (R.B.H. Wills and J.B. Golding, eds.). CRC Press, USA.

Islam A, Altuntas E, Cangi R, Kaya C, Yildiz A (2012) Physicochemical and colour properties of organic and conventional kiwifruits as affected by storage periods. Int $\mathrm{J}$ Food Eng. 8:1556-3758.

Kha TC, Nguyen MH, Roach PD, Parks SE, Stathopoulos C (2013a) Gac fruit: Nutrient and Phytochemical Composition, and Options for Processing. Food Rev Int. 29:92-106.

Kha TC, Nguyen MH, Roach PD, Stathopoulos CE (2013b) Effects of Gac aril microwave processing conditions on oil extraction efficiency, and- $\beta$ carotene and lycopene contents. J Food Eng. 117:486-491.

Kubola J, Siriamornpun S (2011) Phytochemicals and antioxidant activity of different fruit fractions (peel, pulp, aril and seed) of Thai gac (Momordica cochinchinensis Spreng.). Food Chem. 127:1138-1145.
Mclellan MR, Lind LR, Kime RW (1995) Hue angle determinations and statistical analysis for multiquadrant hunter L,a,b data. J Food Quality. 18:235-240.

Nhung DTT, Bung PN, Ha NT, Phong TK (2010) Changes in lycopene and beta carotene contents in aril and oil of gac fruit during storage. Food Chem. 121:326-331.

Olaniyi AF, Umezuruike LO (2013) Effects of maturity status on biochemical content, polyphenol composition and antioxidant capacity of pomegranate fruit arils (cv. 'Bhagwa'). S Afr J Bot. 85:23-31.

Parks SE, Murray CT, Gale DL, Al-khawaldeh B, Spohr LJ (2013) Propagation and production of Gac (Momordica Cochinchinensis Spreng.), A greenhouse case study. Exp Agr. 49:234-243.

Tan SP, Parks S E, Stathopoulos CE, Roach PD (2014) Greenhouse-grown bitter melon: Production and quality characteristics. J Sci Food Agr. 94:1896-1903.

Tran TLH, Raymundo LC (1999) Biosynthesis of carotenoids in bittermelon at high temperature. Phytochemistry. 52:275-280.

Tran XT, Parks SE, Roach PD, Golding JB, Nguyen MH (2015) Effects of maturity on physicochemical properties of Gac fruit (Momordica cochinchinensis Spreng.). Food Sci Nutr. 4:305-314.

Vuong LT, King JC (2003) A method of preserving and testing the acceptability of gac fruit oil, a good source of $\beta$ carotene and essential fatty acids. Food Nutr Bull. 24:224 230.

Weerahewa D, David D (2015) Effect of silicon and potassium on tomato anthracnose and on the postharvest quality of tomato fruit (Lycopersicon esculentum Mill.). J Natl Sci Found Sri. 43:273-280.

Wimalasiri D, Piva T, Urban S, Huynh T (2016) Morphological and genetic diversity of Momordica cochinchinenesis (Cucurbitaceae) in Vietnam and Thailand. Genet Resour Crop Ev. 63:19-33. 